Check for updates

Cite this: RSC Adv., 2018, 8, 29598

\title{
Cromoglycate mesogen forms isodesmic assemblies promoted by peptides and induces aggregation of a range of proteins $\uparrow$
}

\begin{abstract}
Arizza Chiara S. Ibanez, (iD) Elaine Marji iD $\$$ and Yan-Yeung Luk*
Disodium cromoglycate ( $5^{\prime}$ DSCG) belongs to a class of nonamphiphilic molecules that form nematic chromonic liquid crystals in aqueous solutions. As the concentration increases, it is believed that the molecules first form isodesmic assemblies in water, which further align to form liquid crystal phases. However, the reports on isodesmic assemblies of $5^{\prime}$ DSCG have been scarce. Herein, we show that the presence of peptides can promote the isodesmic assembly of 5'DSCG over a broad range of concentrations before reaching the liquid crystal phase. The presence of peptides can lower the $5^{\prime}$ DSCG concentration in the aqueous solution to $1.5 \mathrm{wt} \%$ (from 11-12 wt\%, forming a nematic liquid crystal phase) for isodesmic assembly formation. This result indicates a demixing between 5'DSCG and peptides in aqueous solution. We further explored this demixing mechanism to precipitate a wide range of proteins, namely, lectin A, esterase, lipase, bovine serum albumin, trypsin, and a pilin protein from bacterium Pseudomonas aeruginosa. We found that 5'DSCG caused the aggregation of all these proteins except trypsin. These results, along with past findings, suggest that 5'DSCG isodesmic assemblies have the potential to assist in protein purification and crystallization.
\end{abstract}

Received 18th June 2018

Accepted 5th August 2018

DOI: $10.1039 / \mathrm{c} 8 \mathrm{ra05226c}$

rsc.li/rsc-advances

specific antibody-antigen binding, ${ }^{\mathbf{1 0}}$ and protein crystallization. ${ }^{11}$ Far below the LC phase concentration, at $\sim 0.14 \mathrm{wt} \%$, $5^{\prime}$ DSCG has been demonstrated to promote the crystallization of lysozyme. ${ }^{\mathbf{1 1}}$ More surprisingly, this liquid crystal appears to promote the binding between antigens and antibodies, ${ }^{10}$ while other conventional surfactant-based liquid crystals do not support antigen-antibody binding, presumably due to their ability to denature proteins.

Many novel assembly properties have been observed for this chromonic liquid crystal. ${ }^{15,17,18,20}$ However, it is surprising that the observation and studies for the isodesmic assembly for this class of liquid crystals are scarce ${ }^{\mathbf{1 3 , 1 4 , 2 2 , 2 4}}$ suggesting that the concentration range for isodesmic assembly may be narrow.

In this study, we describe the effect of peptides in promoting 5 'DSCG to form isodesmic assemblies over a wide range of concentrations, i.e., from $1.5 \mathrm{wt} \%$ to $\sim 11-12 \mathrm{wt} \%$, at which the LC phase is observed. We further studied the effect of non-ionic polymers on promoting the isodesmic assembly of $5^{\prime}$ DSCG and used $5^{\prime}$ DSCG to aggregate a range of proteins, including surface appendage pili protein from Pseudomonas aeruginosa.

\section{Experimental}

\section{Chemicals}

Disodium cromoglycate (5'DSCG) (98\% purity) was obtained from TCI Chemicals (Philadelphia, PA). Tryptone, yeast extract, sodium chloride, Tris base, urea, lauryldimethylamine $\mathrm{N}$-oxide and poly(ethylene) glycol (PEG8000) were purchased from 
Fisher Scientific (Fair Lawn, NJ) and were used to make Luria Bertani media and buffers. All aqueous solutions were dissolved in deionized water with resistivity greater than $18.2 \mathrm{M} \Omega \mathrm{cm}$ or deuterium oxide $\left(\mathrm{D}_{2} \mathrm{O}, 99.9 \%\right.$, Cambridge Isotope Laboratories, Inc., Andover, MA). Casamino acids (Amresco, Solon, $\mathrm{OH}$ ), peptone (Bio Basic, Amherst, NY) and casitone (BD Biosciences, MD) were also used. L-amino acids (L-glutamic acid, L-alanine, Larginine), polyvinylpyrrolidone (PVP, MW $\sim 40000$ ), polyvinylalcohol (PVA, MW 9000-10 000), poly-acrylamide (PAAm, MW 9000-10 000), poly(ethylene) glycol (PEG4000), and proteins (lectin A, esterase, lipase, bovine serum albumin and trypsin) were purchased from Sigma Aldrich (St. Louis, MO). Pseudomonas aeruginosa strain PA1244N3 (pPAC46) was obtained from Dr Castric and Dr Horzempa. ${ }^{28,29}$

\section{Isodesmic assembly of disodium cromoglycate (5'DSCG)}

Deionized water was used to prepare all solutions. $5^{\prime}$ DSCG was prepared in Luria Bertani (LB) media (1 wt $\%$ tryptone, $1 \mathrm{wt} \%$ sodium chloride, $0.5 \mathrm{wt} \%$ yeast extract) or mixed with additives including peptides (peptone, casitone, and casamino acids), amino acids (L-glutamic acid, L-alanine, and L-arginine), and urea, and non-ionic polymers, namely, polyvinylpyrrolidone (PVP, MW $\sim 40$ 000), polyvinylalcohol (PVA, MW 900010 000), and poly-acrylamide (PAAm, MW 9000-10 000). The optical density at $600 \mathrm{~nm}\left(\mathrm{OD}_{600}\right)$ of each solution was measured in triplicate using a Biotek ELx800 Microplate Reader.

\section{${ }^{1}$ H NMR spectroscopy measurements}

Stock solutions of $5^{\prime}$ DSCG were prepared and dissolved in either deionized water or LB media ( $1 \mathrm{wt} \%$ tryptone, $1 \mathrm{wt} \%$ sodium chloride, 0.5 wt $\%$ yeast extract). The stock solutions were diluted with the same solvent (deionized water or LB media) to prepare $1 \mathrm{~mL}$-solutions with the final concentrations of 1.5 and $2.5 \mathrm{wt} \% 5^{\prime}$ DSCG. The $1 \mathrm{~mL}$-solutions were lyophilized overnight to remove $\mathrm{H}_{2} \mathrm{O}$. The resulting powder was dissolved in $1 \mathrm{~mL}_{2} \mathrm{O}$ to maintain the same $5^{\prime}$ DSCG concentration of $5^{\prime}$ DSCG. ${ }^{1} \mathrm{H}$ NMR spectroscopy measurements were performed on a 400 $\mathrm{MHz}$ Bruker spectrometer.

\section{Pilin expression}

Pseudomonas aeruginosa mutant strain PA1244N3 carrying pPAC46 plasmid containing the pilA gene (encoding for pilin protein $)^{28,29}$ were grown overnight on $1.5 \mathrm{wt} \%$ agar and treated with tetracycline $\left(50 \mu \mathrm{g} \mathrm{mL} L^{-1}\right)$ and carbenicillin $\left(200 \mu \mathrm{g} \mathrm{mL}^{-1}\right)$ at $37^{\circ} \mathrm{C}$. A single colony from the plate was inoculated overnight in LB media ( $1 \mathrm{wt} \%$ tryptone, $1 \mathrm{wt} \%$ sodium chloride, $0.5 \mathrm{wt} \%$ yeast extract), and then treated with the same concentrations of tetracycline and carbenicillin at $37^{\circ} \mathrm{C}$ with shaking at $250 \mathrm{rpm}$. The overnight culture was grown in $200 \mathrm{~mL} \mathrm{LB}$ media treated with the same concentrations of tetracycline and carbenicillin and then, pilin expression was induced by adding isopropyl $\beta$ - - $^{-}$ 1-thiogalactopyranoside (ITPG) to a final concentration of $1 \mathrm{mM}$. The culture was grown overnight at $37^{\circ} \mathrm{C}$ with shaking at $250 \mathrm{rpm}$. Pilin protein was sheared off the bacterial cells by spinning the culture at $4000 \mathrm{rcf}$ for $30 \mathrm{~min}$ at $4{ }^{\circ} \mathrm{C}$. The cells were discarded, and the supernatant containing pilin was collected and lyophilized overnight. The resulting powder was dissolved in $25 \mathrm{mM}$ Tris buffer ( $\mathrm{pH}=7.5$ ), injected in a prehydrated $10 \mathrm{k}$ MWCO Slide-A-Lyzer dialysis cassette, and dialyzed in the same Tris buffer at $25{ }^{\circ} \mathrm{C}$ for $2 \mathrm{~h}$ twice. The last dialysis was performed overnight at $4{ }^{\circ} \mathrm{C}$. The dialyzed protein solution was then lyophilized overnight. Purity of the protein was checked by SDS PAGE analysis with a $15 \%$ separating gel and $4 \%$ stacking gel.

\section{Truncated pilin expression and purification}

The pPAC46 plasmid containing the pilA gene was extracted from PA1244N3 (pPAC46) using the PureLink ${ }^{\mathrm{TM}}$ Quick Plasmid Miniprep Kit from Invitrogen. Polymerase chain reaction (PCR) was performed to clone the truncated pilA gene, removing the DNA base pairs encoding the first 37 amino acid residues of the pilin protein from the N-terminus. The PCR product from the full-length pilin plasmid was obtained using the following primers: forward: 5'-CAGGTGACCCGTGCCGTGAGTG-3' and reverse: $5^{\prime}$ TTAGGATTTCGGGCAATTAGCCGGAG-3'. The truncated pilA gene was ligated in the PET SUMO vector to produce a SUMO-pilin construct. The sequence of the purified plasmid was checked by sequencing to ensure no errors. The SUMOpilin plasmid was transformed in Escherichia coli BL21 cells by heat-shock method. The transformed BL21 cells were plated on a LB agar (3 wt\%) plate treated with kanamycin $\left(50 \mu \mathrm{g} \mathrm{mL}{ }^{-1}\right)$, and then incubated overnight at $37{ }^{\circ} \mathrm{C}$. A single colony was picked and inoculated overnight in $20 \mathrm{~mL} \mathrm{LB}$ media with kanamycin $\left(50 \mu \mathrm{g} \mathrm{mL}^{-1}\right)$. The BL21 overnight culture was grown in $1 \mathrm{~L} \mathrm{LB}$ media with the same concentration of kanamycin. Truncated pilin expression was induced by adding IPTG to a final concentration of $0.5 \mathrm{mM}$ when the culture reached an $\mathrm{OD}_{600}$ of $\sim 0.6$. The culture was grown overnight at $18{ }^{\circ} \mathrm{C}$ with shaking at $250 \mathrm{rpm}$. Bacteria cells were harvested by centrifugation for 30 minutes at $4000 \mathrm{rcf}$ at $4{ }^{\circ} \mathrm{C}$. Extraction and purification of the protein was performed by resuspending the bacterial cells in lysis buffer $(25 \mathrm{mM}$ Tris, $100 \mathrm{mM} \mathrm{NaCl}, 20 \mathrm{mM}$ imidazole, $10 \%$ glycerol, $0.1 \%$ lauryldimethylamine $N$-oxide, $\mathrm{pH}$ $=7.5$ ) and sonicated with $20 \mathrm{~s}$ pulses for $15 \mathrm{~min}$. The sonicated cells were centrifuged for $30 \mathrm{~min}$ at $20000 \mathrm{rcf}$ at $4{ }^{\circ} \mathrm{C}$. The supernatant (containing SUMO-pilin) was subjected to a NiNTA (nickel nitrilotriacetic acid) agarose affinity column and eluted with elution buffer ( $25 \mathrm{mM}$ Tris, $100 \mathrm{mM} \mathrm{NaCl}, 250 \mathrm{mM}$ imidazole, $\mathrm{pH}=7.5$ ). Fractions containing protein were collected and concentrated to $\sim 2 \mathrm{~mL}$ using a Millipore centrifugal filter concentrator $10 \mathrm{k}$ MWCO. The concentrated protein was buffer exchanged with SUMO buffer (50 mM Tris, $50 \mathrm{mM} \mathrm{NaCl}, \mathrm{pH}=8.0$ ), concentrated to $\sim 2 \mathrm{~mL}$. The SUMO tag was cleaved by adding $0.5 \mathrm{mM}$ EDTA, $1 \mathrm{mM}$ DTT and SUMO protease (200: 1 protease : protein) and incubated at $30{ }^{\circ} \mathrm{C}$ for $3 \mathrm{~h}$. The SUMO buffer was then exchanged with storage buffer (25 mM Tris, $100 \mathrm{mM} \mathrm{NaCl}, \mathrm{pH}=7.5$ ) to remove DTT and EDTA. Fractions containing protein were collected and concentrated. The cleaved truncated pilin was eluted through the Ni-NTA column, and the process was completed with a final buffer exchange with the storage buffer. Fractions containing the 
protein were collected and concentrated, and the final protein concentration was checked by UV-Vis absorption spectroscopy at $280 \mathrm{~nm}\left(A_{280}\right)$. Purity of the protein was analyzed by SDS PAGE using a $15 \%$ separating gel and $4 \%$ stacking gel.

\section{Hanging drops precipitation of proteins}

Proteins (lectin A, esterase, lipase, bovine serum albumin, trypsin, and whole and truncated pilin proteins from $P$. aeruginosa) were prepared in $25 \mathrm{mM}$ Tris $(\mathrm{pH}=7.5)$ at varying concentrations. Reservoir solutions were prepared individually with different concentrations of $\mathrm{NaCl}$ or $5^{\prime} \mathrm{DSCG}$ in the same buffer $(25 \mathrm{mM}$ Tris, $\mathrm{pH}=7.5)$. Both protein and reservoir solutions were passed through a $0.2 \mu \mathrm{m}$ syringe filter to remove any impurities. Hanging drops were prepared by mixing equal volumes $(2.5 \mu \mathrm{L}$ each) of the filtered protein and reservoir solutions and suspending them as inverted drops on a coverslip over a well with $350 \mu \mathrm{L}$ reservoir solution. Aggregation in the drops was observed within 5-15 days of incubation at ambient temperature.

\section{Results and discussion}

Additives such as ions and water-soluble organic molecules can have an impact on the transition concentration of $5^{\prime}$ DSCG from isotropic solutions to nematic liquid crystal phases. ${ }^{13,17,23,30-32}$ The isodesmic assembly formation is predicted to be a step towards the formation of the LC phase as these isodesmic assemblies align in solution..$^{\mathbf{1 3 , 1 4 , 2 7}}$ However, the extensive studies and characterization of these isodesmic assemblies are lacking. Some studies showed the assembly of $5^{\prime}$ DSCG molecules form small noncovalent oligomers, which is consistent with the formation of isodesmic assemblies. ${ }^{\mathbf{1 8 , 3 3}}$ Herein, we discovered a simple system containing chemical additives that promoted the formation of large and readily detectable isodesmic assembly of $5^{\prime}$ DSCG (Fig. 1).

\section{Components of Luria Bertani media promote the isodesmic assembly of $5^{\prime}$ DSCG}

To explore potential biological applications using $5^{\prime}$ DSCG phases, we first conducted a study on the effect of Luria Bertani (LB) media for culturing bacteria (1 wt\% tryptone, 1 wt $\%$ sodium chloride, $0.5 \mathrm{wt} \%$ yeast extract) on the assembly and

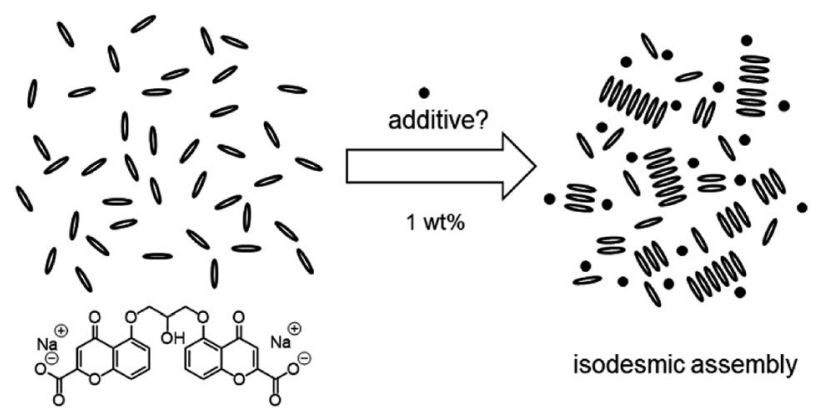

Fig. 1 Schematic of the formation of an isodesmic assembly of $5^{\prime}$ DSCG, induced by chemical additives.

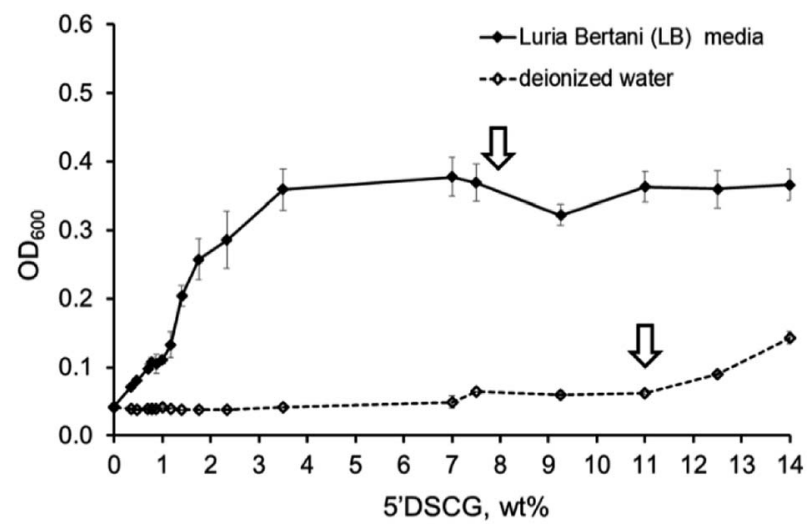

Fig. 2 Optical density $\left(O D_{600}\right)$ measurements versus the concentrations of 5'DSCG in deionized water and in LB medium. Arrows indicate the concentrations at which the liquid crystal (LC) phase forms.

phase property of $5^{\prime}$ DSCG. Initial studies show that LB media caused $5^{\prime}$ DSCG to form nematic phases at a lower concentration than in deionized water ( $8 \mathrm{wt} \%$ rather than $11 \mathrm{wt} \%$ ) (Fig. S1, ESI $\dagger$ ), suggesting that the components of LB media induced the assembly of $5^{\prime}$ DSCG in aqueous solution. Further study of the isotropic solutions of $5^{\prime}$ DSCG in LB media led to the discovery that isodesmic assemblies of $5^{\prime}$ DSCG can be readily measured by the light scattering of the solution via the absorbance at $600 \mathrm{~nm}\left(\mathrm{OD}_{600}\right)$. Measuring $\mathrm{OD}_{600}$ is commonly used for measuring bacteria densities via light scattering of the bacterial cells. Isodesmic assemblies, if existing, comprise different oligomers and polymers in equilibrium. ${ }^{13-15,25,27}$ Light scattering of the solution provides a readily accessible method to detect the presence of these isodesmic assemblies in solution.

Measurement of the optical density $\mathrm{OD}_{600}$ revealed the formation of assemblies of $5^{\prime}$ DSCG. The $\mathrm{OD}_{600}$ of $5^{\prime}$ DSCG in deionized water did not change significantly until the concentration reached the transition to form the liquid crystal phase (11-12 wt\%). However, in $\mathrm{LB}$ media, the $\mathrm{OD}_{600}$ readings increase rapidly at a concentration starting at around $1.5 \mathrm{wt} \%$ of $5^{\prime}$ DSCG, and then reaching a plateau at around $\sim 3.5 \mathrm{wt} \%$ (Fig. 2). These low concentrations are of a large contrast to the nematic concentrations of $5^{\prime}$ DSCG in water (11-14 wt $\left.\%\right)$. Between the saturation of the $\mathrm{OD}_{600}$ at around $3.5 \mathrm{wt} \%$ and the appearance of liquid crystals at around $8 \mathrm{wt} \%$, we believe that this concentration range is saturated with isodesmic assemblies of increasing sizes and not with increasing number of assemblies.

To confirm that the rise in the $\mathrm{OD}_{600}$ readings is due to the assembly of $5^{\prime}$ DSCG in LB media rather than the aggregation of LB components, we studied the proton NMR spectra of the $5^{\prime}$ DSCG in $\mathrm{D}_{2} \mathrm{O}$ and in LB media (Fig. 3). Proton $\left({ }^{1} \mathrm{H}\right)$ NMR has been used to study $5^{\prime}$ DSCG assembly in solution. ${ }^{33}$ The selfassembly of $5^{\prime}$ DSCG results in the slow diffusion of the molecules and causes the proton peaks to broaden in the ${ }^{1} \mathrm{H}$ NMR spectra. Furthermore, an upfield shift is usually observed due to the protons being shielded, resulting from intramolecular assembly. ${ }^{15,18,33}$ These results enable a direct correlation between assembly characteristics and the identity of molecules 


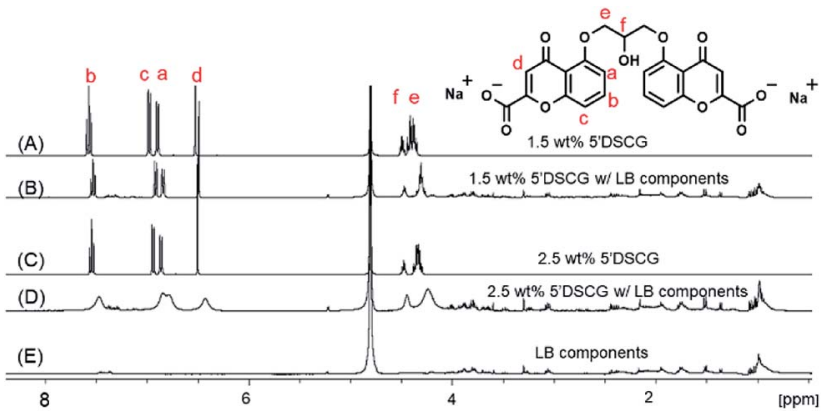

Fig. $3{ }^{1} \mathrm{H}$ NMR spectra of $1.5 \mathrm{wt} \% 5^{\prime} \mathrm{DSCG}$ without (A) and with (B) LB components, 2.5 wt\% 5'DSCG without (C) and with (D) LB components, and (E) LB components in $\mathrm{D}_{2} \mathrm{O}$. The protons of $5^{\prime} \mathrm{DSCG}$ and peak assignments are labelled in red.

that assemble in isotropic solutions. We prepared samples of $1.5 \mathrm{wt} \% 5^{\prime} \mathrm{DSCG}$ and $2.5 \mathrm{wt} \% 5^{\prime} \mathrm{DSCG}$ with and without LB components in $\mathrm{D}_{2} \mathrm{O}$ (see Experimental section) as well as with only LB components in $\mathrm{D}_{2} \mathrm{O}$. The presence of LB components ( $1 \mathrm{wt} \%$ tryptone, $1 \mathrm{wt} \%$ sodium chloride, $0.5 \mathrm{wt} \%$ yeast extract) caused the proton signals of $5^{\prime}$ DSCG to broaden and shift upfield. When LB components were present in $1.5 \mathrm{wt} \% 5^{\prime} \mathrm{DSCG}$, the isopropyl linkage protons $\mathrm{H}_{\mathrm{e}}$ and $\mathrm{H}_{\mathrm{f}}$ at 4.38 and $4.49 \mathrm{ppm}$ were shifted upfield to 4.30 and $4.47 \mathrm{ppm}$, respectively. The aromatic protons $\mathrm{H}_{\mathrm{d}}, \mathrm{H}_{\mathrm{a}}, \mathrm{H}_{\mathrm{c}}$ and $\mathrm{H}_{\mathrm{b}}$ at 6.52, 6.90, 6.99 and $7.57 \mathrm{ppm}$ shifted upfield to $6.49,6.85,6.92$ and $7.52 \mathrm{ppm}$, respectively. At this concentration ( $1.5 \mathrm{wt} \%$ of $5^{\prime} \mathrm{DSCG}$ ), no significant broadening of the peaks was observed due to the presence of LB components, but a new splitting fine structure of $\mathrm{H}_{\mathrm{e}}$ was observed, suggesting a change in the molecular conformation. In contrast, for $2.5 \mathrm{wt} \% 5^{\prime} \mathrm{DSCG}$ with LB components, we observed significant broadening and upfield shifts in the peaks as compared to that without LB components. The isopropyl linkage protons $\mathrm{H}_{\mathrm{e}}$ and $\mathrm{H}_{\mathrm{f}}$ shifted upfield from 4.33 and $4.47 \mathrm{ppm}$ to 4.24 and $4.45 \mathrm{ppm}$, respectively, while the aromatic protons $\mathrm{H}_{\mathrm{d}}, \mathrm{H}_{\mathrm{a}}, \mathrm{H}_{\mathrm{c}}$ and $\mathrm{H}_{\mathrm{b}}$ at 6.50, 6.87, 6.94 and 7.54 shifted upfield to $6.43,6.80,6.85$ and $7.47 \mathrm{ppm}$, respectively. These results are consistent with the molecular aggregation of $5^{\prime} \mathrm{DSCG}^{33}$ and indicate that presence of LB components has caused assembly of $5^{\prime}$ DSCG at concentrations as low as $1.5 \mathrm{wt} \%$. There was no noticeable peak broadening of the LB components with or without the presence of $5^{\prime}$ DSCG.

The observed peak broadening and shifts are consistent with the formation of slow tumbling assemblies of $5^{\prime}$ DSCG in the solution. The past study by Robinson et al. showed that the proton NMR signals of $5^{\prime}$ DSCG broaden and shift upfield rapidly from concentrations of $1 \mathrm{wt} \%$ to about $6 \mathrm{wt} \% .^{33}$ Beyond $6 \mathrm{wt} \%$, the peak broadening starts to plateau; however, the peaks continue to shift upfield. They suggested that the rapid peak broadening was caused by the formation of $5^{\prime}$ DSCG oligomers that are not micelles, and that the slow tumbling at concentrations above $6 \mathrm{wt} \%$ was due to large micelle-like aggregates. Our results using light scattering revealed that in pure water, no significant optical density reading was observed until the concentration of $5^{\prime}$ DSCG reached $12 \mathrm{wt} \%$. We believe that the light scattering measurement is sensitive to large molecular assemblies, whereas NMR is sensitive to small molecular assemblies that lead to reduced molecular dynamics. Interestingly, we observed that the presence of LB components caused the optical density reading to increase when the concentration of $5^{\prime}$ DSCG was as low as $1.5 \mathrm{wt} \%$ (Fig. 2). This result suggests that the presence of certain components in the LB media promotes readily detectable and large isodesmic assemblies, whereas without the presence of additives, 5'DSCG may only progressively form small oligomers. Collectively, these results indicated that LB components have a significant impact on promoting $5^{\prime}$ DSCG to form large aggregates in water, and these aggregates did not form the liquid crystal phase until about $8 \mathrm{wt} \%$. We note that the fine structure (splitting pattern) of the ${ }^{1} \mathrm{H}$ NMR signal of the methylene unit of the isopropyl linkage $\left(\mathrm{H}_{\mathrm{e}}\right)$ is more collapsed with the presence of LB components (Fig. 3B) than without LB (Fig. 3A). When the concentration of $5^{\prime}$ DSCG is increased in water without LB components, we also observed a similar collapse of the fine structure (Fig. S2, ESI $\dagger$ ). These results suggest that there is a change in the average conformation of the molecule when the molecules are in the assembly as compared to when they are individually solvated in solution. However, the presence of LB components only lowers the concentration of assembly formation without causing a significant difference to the assembly structure formed in water without LB components.

To explore the assembly structure of $5^{\prime}$ DSCG, we studied the nuclear overhauser effect (NOE) of the sample with and without LB components. On examining the NOESY spectra of $5^{\prime}$ DSCG (2 wt\%) with LB components, we did not observe any NOE signals between the LB components and the 5'DSCG molecules (Fig. S3, ESI $\dagger$ ). This result suggests that there is no direct molecular interaction (within $5 \AA$ ) between $5^{\prime}$ DSCG and LB components.

On comparing the NOESY spectra of $2 \mathrm{wt} \% 5^{\prime} \mathrm{DSCG}$ with and without LB components, we observed additional NOE cross peaks for $5^{\prime}$ DSCG when LB components were present (Fig. 4A, B and $\mathrm{S} 4, \mathrm{ESI} \dagger)$ between the isopropyl linkage protons $\left(\mathrm{H}_{\mathrm{e}}\right.$ and $\left.\mathrm{H}_{\mathrm{f}}\right)$ and the aromatic protons $\left(\mathrm{H}_{\mathrm{d}}, \mathrm{H}_{\mathrm{a}}, \mathrm{H}_{\mathrm{c}}\right.$, and $\left.\mathrm{H}_{\mathrm{b}}\right)$, which were not present in the sample without LB components. Furthermore, although an NOE cross peak between $\mathrm{H}_{\mathrm{e}}$ and $\mathrm{H}_{\mathrm{a}}$ is observed for

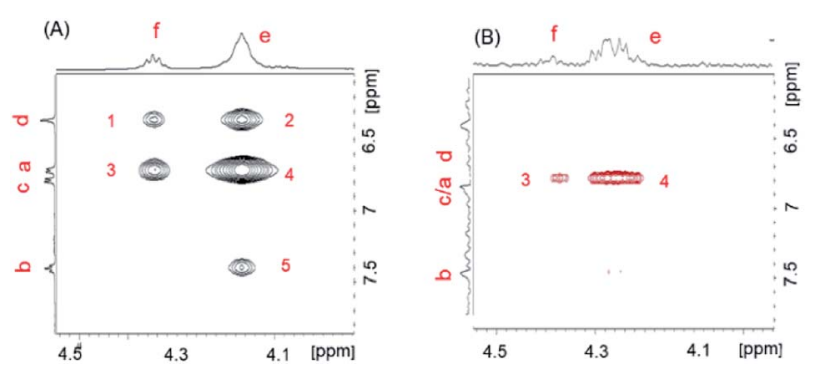

Fig. 4 NOESY spectra of 2 wt\% 5'DSCG with (A) and without (B) LB components in $\mathrm{D}_{2} \mathrm{O}$. With $\mathrm{LB}$, cross peaks 1,2 , and 5 are intermolecular NOEs, and 3 and 4 are a mixture of inter- and intramolecular NOEs. Without LB, cross peaks 3 and 4 are intramolecular NOEs. 
both samples, this NOE cross peak has the same phase (with respect to the diagonal) for the sample with LB components and the NOE cross peak has an opposite phase (with respect to the diagonal) for the sample without LB. NOE cross peaks having an opposite phase (with respect to the diagonal) are indicative of a fast dynamic of the conformational changes. Collectively, these results indicate that without LB components, the NOE cross peaks that have the opposite phase arise due to the intramolecular interaction between protons $\mathrm{H}_{\mathrm{e}}$ and $\mathrm{H}_{\mathrm{a}}$ within a 5'DSCG molecule. With LB components, cross peak 1 of protons $\mathrm{H}_{\mathrm{f}}$ and $\mathrm{H}_{\mathrm{d}}$, cross peak 2 of protons $\mathrm{H}_{\mathrm{e}}$ and $\mathrm{H}_{\mathrm{d}}$, and cross peak 5 of $\mathrm{H}_{\mathrm{e}}$ and $\mathrm{H}_{\mathrm{b}}$ are intermolecular NOE transfers between stacked 5'DSCG molecules, whereas cross peak 3 of protons $\mathrm{H}_{\mathrm{f}}$ and $\mathrm{H}_{\mathrm{a}} / \mathrm{H}_{\mathrm{c}}$ and cross peak 4 of protons $\mathrm{H}_{\mathrm{e}}$ and $\mathrm{H}_{\mathrm{a}} / \mathrm{H}_{\mathrm{c}}$ result from a mixture of intermolecular and intramolecular NOE signals.

To confirm the nature of isodesmic assembly, we studied NOESY as a function of temperature. We first established that the assemblies "melted" at a relatively low temperature $(\sim 31-33$ $\left.{ }^{\circ} \mathrm{C}\right)$. We then plotted the NOE cross peak intensities of the protons of $5^{\prime} \mathrm{DSCG}$ (Fig. 5A-E) as a function of temperature between ambient conditions $\left(21^{\circ} \mathrm{C}\right)$ and complete melting of the assembly. In general, we observed that as the temperature was decreased from $33{ }^{\circ} \mathrm{C}$ (when there was no intermolecular NOE observed), the intermolecular NOEs emerged and their intensities increased. Because cross peak 2 represents solely the NOE between the stacked molecules, this signal is an indication of the assembly progression. Plotting the intensity of cross peak 2 versus temperature (Fig. 5F) reveals a concave curve rather than a convex curve. We note that plots of intensity versus temperature for all the observed NOE signals from $5^{\prime}$ DSCG exhibited a concave shape (Fig. S5, ESI $\dagger$ ). This concave relation
(A)

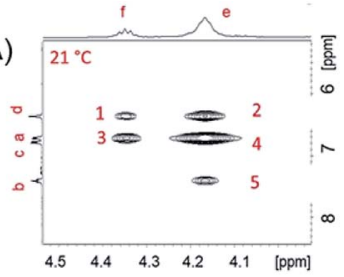

(B)

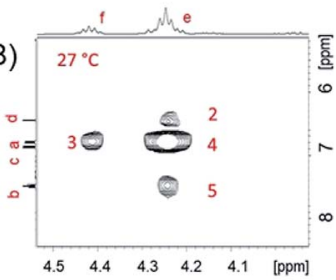

(C)

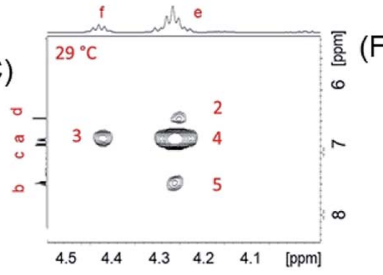

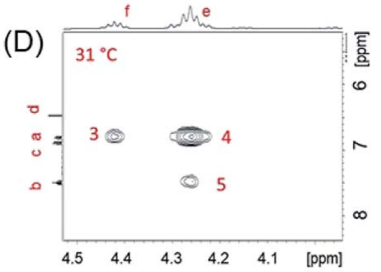

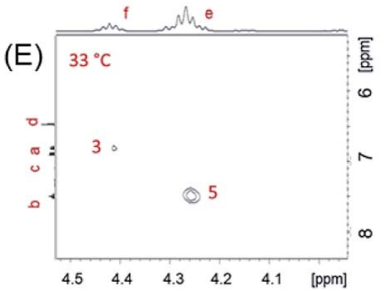

(F)

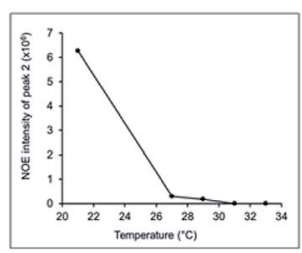

Fig. 5 NOESY spectra of 2 wt\% $5^{\prime}$ DSCG with LB components at different temperatures: $21^{\circ} \mathrm{C}(\mathrm{A}), 27^{\circ} \mathrm{C}(\mathrm{B}), 29^{\circ} \mathrm{C}(\mathrm{C}), 31^{\circ} \mathrm{C}(\mathrm{D})$, and $33^{\circ} \mathrm{C}(\mathrm{E})$. Plot of intensity of NOE cross peak 2 vs. temperature (F). supports that the disassembly process is gradual rather than cooperative, and is consistent with an isodesmic assembly or disassembly process.

\section{Peptides promote the isodesmic assembly of $5^{\prime}$ DSCG}

LB media consists of $1 \mathrm{wt} \%$ tryptone, $1 \mathrm{wt} \%$ sodium chloride, and $0.5 \mathrm{wt} \%$ yeast extract. The tryptone and yeast extracts are mixtures of mainly peptides. We examined each of these three components individually to determine which component promoted the isodesmic assembly of $5^{\prime}$ DSCG. At $7 \mathrm{wt} \%$ in water, $5^{\prime}$ DSCG alone does not give a significant $\mathrm{OD}_{600}$ reading. Adding each LB component at this $5^{\prime}$ DSCG concentration can potentially induce the formation of $5^{\prime}$ DSCG isodesmic assemblies, leading to measurable optical densities (absorbance at $600 \mathrm{~nm}$ ). We found that mixing $7 \mathrm{wt} \% 5^{\prime}$ DSCG with tryptone or yeast extract caused an increase in $\mathrm{OD}_{600}$ readings, but at higher concentrations than those in LB media. LB media contains $1 \mathrm{wt} \%$ of tryptone and $0.5 \mathrm{wt} \%$ of yeast extract. For tryptone alone, we observed an increase in $\mathrm{OD}_{600}$ only when the tryptone concentration reached $3 \mathrm{wt} \%$. For yeast extract alone, we observed an increase in $\mathrm{OD}_{600}$ only when the concentration reached 2 wt $\%$ (Fig. S6, ESI $\dagger$ ). Sodium chloride did not cause an increase in the $\mathrm{OD}_{600}$ readings. These results led us to believe that peptides caused a demixing with $5^{\prime}$ DSCG, which further promoted $5^{\prime}$ DSCG to form isodesmic assembly, while other ions only play a secondary role in assisting the demixing between peptides and $5^{\prime}$ DSCG.

We also tested peptone and casitone, which are similar peptide mixtures to tryptone used for culturing bacteria. Adding these peptide mixtures at similar concentrations as tryptone in LB media $(\sim 1 \mathrm{wt} \%)$ to a range of $5^{\prime} \mathrm{DSCG}$ concentrations revealed that these peptides also promoted the isodesmic assembly of $5^{\prime}$ DSCG (Fig. 6). We observed a similar light scattering trend between the LB components (Fig. 2) and other peptides when they were added to a range of 5 'DSCG concentrations. The addition of tryptone caused the $\mathrm{OD}_{600}$ readings to increase at $2 \mathrm{wt} \% 5^{\prime}$ DSCG and remained at a similar $\mathrm{OD}_{600}$ $(\sim 0.2)$ for the rest of the high concentrations we studied. For peptone and casitone, the $\mathrm{OD}_{600}$ readings started to increase at $2 \mathrm{wt} \%$ of $5^{\prime}$ DSCG until reaching a plateau at around $6 \mathrm{wt} \%$ of

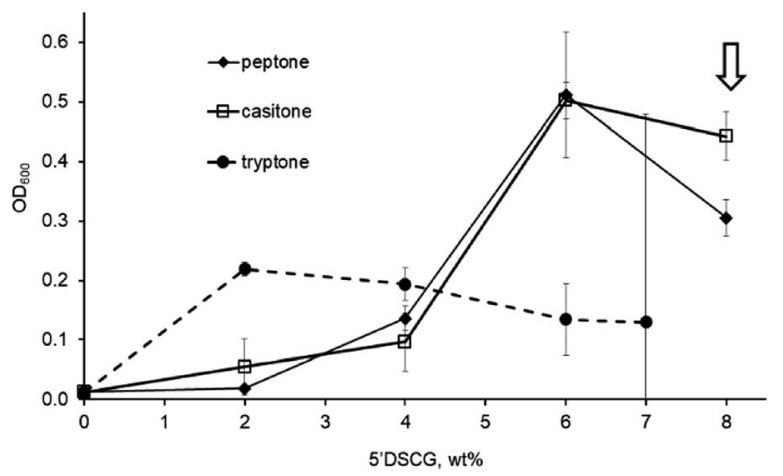

Fig. 6 Optical density $\left(\mathrm{OD}_{600}\right)$ measurements of the solutions containing $1 \mathrm{wt} \%$ peptide mixtures (peptone, casitone, and tryptone) mixed with different concentrations of 5'DSCG. The arrow indicates 5'DSCG concentration at which the liquid crystal (LC) droplets appear. 


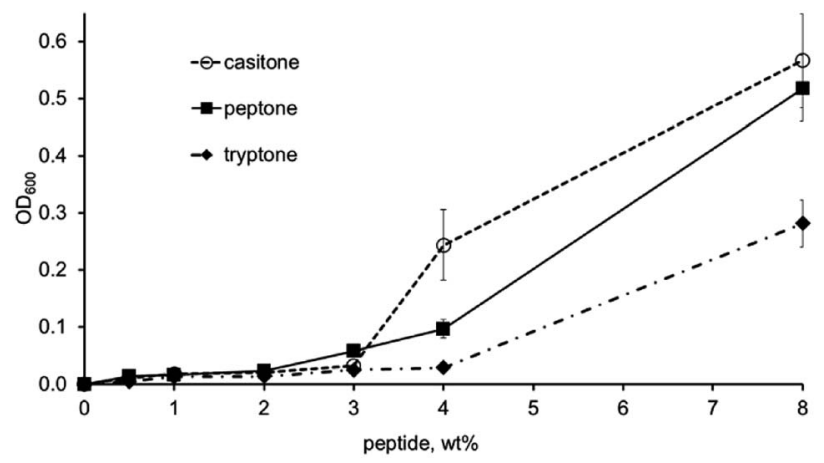

Fig. 7 Optical density $\left(O D_{600}\right)$ measurements of solutions containing 3 wt\% 5'DSCG mixed with different concentrations of peptides: casitone, peptone, and tryptone.

5 DSCG. Overall, these results show that among the LB media components, peptides are the primary cause for promoting assemblies of $5^{\prime}$ DSCG in water that are detectable by light scattering.

While $1 \mathrm{wt} \%$ of these peptide mixtures promoted the aggregation signal of $5^{\prime}$ DSCG differently, we explored the effect of different concentrations of peptide mixtures on a fixed amount of $5^{\prime}$ DSCG (Fig. 7). We observed that the addition of increasing concentrations of peptides (peptone, tryptone, or casitone) to $3 \mathrm{wt} \% 5^{\prime} \mathrm{DSCG}$ caused the formation of isodesmic assemblies detectable by $\mathrm{OD}_{600}$ measurements. The amount of peptide needed ranges between $2 \mathrm{wt} \%$ and $4 \mathrm{wt} \%$ (peptone at $\sim 2 \mathrm{wt} \%$, casitone at $\sim 3 \mathrm{wt} \%$, and tryptone at $\sim 4 \mathrm{wt} \%)$. These results suggest that effect of peptides on $5^{\prime}$ DSCG is quite general.

Collectively, we believe that these results indicate a demixing process between the peptides and 5'DSCG molecules in solution. As the assemblies of $5^{\prime}$ DSCG stay in solution rather than forming precipitates, we believe that water molecules are sequestered and bound to the assemblies for the solvation of the assemblies in water. Thus, the presence of peptides $(\sim 1 \mathrm{wt} \%)$ causes the transition of $5^{\prime}$ DSCG (individual) $\rightarrow$ $5^{\prime}$ DSCG (isodesmic assembly) in aqueous solution. To further confirm that peptides are the primary components that enabled the assembly of $5^{\prime}$ DSCG, we tested the components, including individual amino acids, salts, and urea, and found that none of these small molecules promoted the isodesmic assembly of $5^{\prime}$ DSCG in solution (Fig. S7, ESI $\dagger$ ).

\section{Non-ionic polymers do not promote $5^{\prime}$ DSCG to form isolated isodesmic assemblies}

We have previously shown that certain non-ionic water-soluble polymers, such as polyvinylpyrrolidone (PVP), polyvinylalcohol (PVA), and poly-acrylamide (PAAm), when mixed with $5^{\prime}$ DSCG, can cause a water-in-water emulsion, for which $5^{\prime}$ DSCG assemblies align to form water-based LC droplets in aqueous solution. ${ }^{\mathbf{1 5 , 1 7}}$ Herein, we studied the effect of the three nonionic polymers (PVP, PVA and PAAm) on the isodesmic assembly formation of $5^{\prime} \mathrm{DSCG}$. The non-ionic polymers were mixed with isotropic solutions of $5^{\prime}$ DSCG ( $7 \mathrm{wt} \%$ ) and the

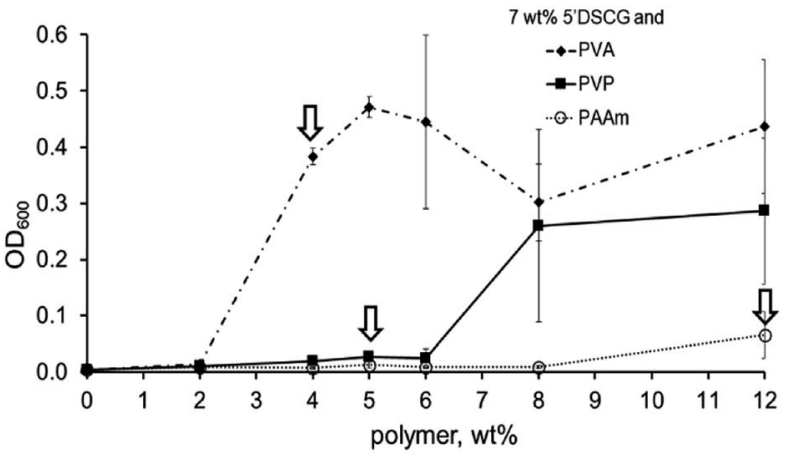

Fig. 8 Optical density $\left(\mathrm{OD}_{600}\right)$ measurements of solutions containing 7 wt\% 5'DSCG mixed with different concentrations of non-ionic polymers: polyvinylalcohol (PVA, $M_{w} \sim 9000-10000$ ), poly-vinylpyrrolidone (PVP, $\left.M_{w} \sim 40000\right)$, and poly-acrylamide (PAAm, $M_{w} \sim$ 9000-10 000). Arrows indicate the polymer concentration mixed with 7 wt\% 5'DSCG at which the liquid crystal (LC) droplets appear.

optical density $\left(\mathrm{OD}_{600}\right)$ was measured as a function of the polymer concentration (Fig. 8). At $7 \mathrm{wt} \% 5^{\prime} \mathrm{DSCG}$, we recorded the $\mathrm{OD}_{600}$ of the $5^{\prime} \mathrm{DSCG} /$ polymer mixtures when the PVP concentration reached $8 \mathrm{wt} \%$ and PVA concentration reached $4 \mathrm{wt} \%$. LC droplet phases were also observed at around these concentrations, indicating that the promotion of isodesmic assemblies is likely accompanied with the formation of LC phases and that there is a narrow range of concentrations over which only isodesmic assembly forms. Interestingly, over a broad range of concentrations studied (0-12 wt\%), PAAm did not cause any significant increase in $\mathrm{OD}_{600}$ readings when mixed with $7 \mathrm{wt} \%$ of $5^{\prime}$ DSCG (Fig. 8). Moreover, we also tested the effect of non-ionic polymers on $3 \mathrm{wt} \% 5^{\prime} \mathrm{DSCG}$, and no measurable isodesmic assembly was detected (Fig. S8, ESI $\dagger$ ). We note that the liquid crystal phases mixed with isotropic solution was observed at $4 \mathrm{wt} \%$ and $5 \mathrm{wt} \%$ of PVA and PVP, respectively, which contributed to the large errors of the scattering at higher concentrations.

Furthermore, we note that there is a correlation between the ability of a polymer to promote isodesmic assembly and the type of liquid crystal droplet that forms. Polymers PVP and PVA promoted isodesmic assemblies of $5^{\prime}$ DSCG (along with liquid crystal droplets) at relatively low concentrations, whereas PAAm did not promote isodesmic assembly. PVP and PVA cause spherical liquid crystal droplets with $5^{\prime}$ DSCG

Table 1 Correlation between the effect of polymers on 5'DSCG assembly and the types of liquid crystal droplets promoted by the polymers

\begin{tabular}{|c|c|c|c|}
\hline & $\begin{array}{l}\text { Isodesmic } \\
\text { assembly }^{a}\end{array}$ & Droplet shape ${ }^{b}$ & $\begin{array}{l}\text { Assembly orientation } \\
\text { in droplets }\end{array}$ \\
\hline PVP & Yes $^{e}$ & Spherical $^{c}$ & Perpendicular ${ }^{f}$ \\
\hline PVA & Yes $^{e}$ & Spherical $^{d}$ & Perpendicular ${ }^{f}$ \\
\hline PAAm & No & Ellipsoidal $^{d}$ & Parallelf \\
\hline
\end{tabular}

${ }^{a}$ By optical density measurement. ${ }^{b}$ Shape of the water-based liquid crystal droplets in a polymer aqueous solution. ${ }^{c}$ See ref. $23 .{ }^{d}$ See ref. $13 .^{e}$ Mixed with liquid crystal droplets. ${ }^{f}$ To the surface of the droplets. 
assemblies that align perpendicular to the droplet surfaces, whereas PAAm causes ellipsoidal droplets with the assemblies aligned parallel to the droplet surfaces (Table 1).

\section{Protein aggregation induced by $5^{\prime}$ DSCG}

We examined the effect of the presence of proteins on the assembly behaviour of $5^{\prime}$ DSCG. The proteins have lower solubility than peptides and readily cause foaming when concentration increases. At the usual operable concentrations of proteins ( 0.5 to $5 \mathrm{mg} \mathrm{mL} \mathrm{m}^{-1}$, or 0.05 to $0.5 \mathrm{wt} \%$ ), we did not observe any promotion of isodesmic assemblies that was detectable by scattering. However, the formation of isodesmic assemblies of $5^{\prime}$ DSCG in the presence of peptides does suggest a demixing process between the two components. In a previous study, ${ }^{11}$ we have shown that $5^{\prime}$ DSCG at a low concentration $(\sim 0.14 \mathrm{wt} \%$ or $\sim 2.74 \mathrm{mM})$ caused the crystallization of lysozyme. Furthermore, $5^{\prime}$ DSCG appears to be non-disruptive to protein folding by being able to facilitate the specific recognition and binding between proteins and their antibodies. ${ }^{10}$ Based on these observations, we explore the use of $5^{\prime}$ DSCG to precipitate or crystallize a range of different proteins in solution.

Chemical agents that can precipitate or aggregate proteins are critical for protein crystallization; ${ }^{34-42}$ yet, there is no theoretical or empirical set of rules to guide the choice of precipitants in crystallizing a specific protein. For this reason, chemical screening kits have been developed to screen for large sets of reagents and conditions for protein crystallization. ${ }^{34-38}$ Surprisingly, poly(ethylene glycol) (PEG) is often one of the major components for these kits and research. ${ }^{34-37}$ PEG does not denature proteins and presumably excludes proteins in the solution. ${ }^{39-41}$ Other non-denaturing chemicals such as cyclodextrins have also been used as nucleants for seeding protein aggregates and crystals. ${ }^{42}$ For this consideration, we note that $5^{\prime}$ DSCG also does not denature protein folding. ${ }^{10}$ Furthermore, it appears that using PEG as a precipitant for protein crystallization requires a higher concentration range $(\sim 5-45 \mathrm{wt} \%)^{35-39}$ compared to $5^{\prime}$ DSCG shown in this study (see below). Herein, we examined the effect of $5^{\prime}$ DSCG on the aggregation or crystallization of a range of proteins, including lectin A, esterase, lipase, bovine serum albumin, trypsin and a pilin monomer from Pseudomonas aeruginosa as well as the truncated version of the pilin protein monomer.

Pilin is a general class of proteins comprising an $\alpha$-helix and a $\beta$-sheet domain. These proteins are collected and assembled inside the bacteria and extended (and retracted) as appendages on the surface of the bacteria. The appendage consists of circular assemblies of 4-5 pilin monomers that linearly stack on top of each assembly. These appendages can extend and retract in response to chemical signals or environmental stimuli and are responsible for a wide range of the biological function of bacteria including swarming motility, twitching motility, recognizing sugar moieties (asialo- $\mathrm{GM}_{1}$ ) on mammalian cells, and the hydrophobic surface of abiotic surfaces. ${ }^{43-52}$ Vaccine development has also been explored for this class of proteins. ${ }^{47-49}$
Because of the importance of this class of proteins, vaccine development has been explored for these proteins, and several crystal structures of pilin exist, ${ }^{49-52}$ most of which are of the truncated versions of pilin. ${ }^{\mathbf{4 9 , 5 1 , 5 2}}$ Moreover, the crystal structures of ligand-bound pilin complexes are yet to be confirmed. Castric and Horzempa, along with earlier groups, expressed the whole pilin protein ${ }^{28,29}$ and precipitated it with poly(ethylene glycol) (PEG8000). ${ }^{29,53}$ Unfortunately, PEG8000 cannot be easily removed after pilin is precipitated from the culture media. It is believed that PEG8000 molecules wrap around each pilin protein. Consequently, the presence of PEG8000 hinders most structure-function characterization of pilin. We thus expressed and purified a truncated version of the pilin from $P$. aeruginosa by removing the first 37 amino acids from the $\mathrm{N}^{\prime}$-terminus (see Experimental section) for two reasons. First, expressing truncated pilin uses conventional nickel affinity chromatography (Ni-NTA column) for purification, eliminating the need of PEG8000 in the purification process. Second, the truncated pilin still retains its putative ligand-binding site on the protein upon removal of the hydrophobic N-terminal $\alpha$-helix, but presents a more compact structure for crystallization studies. $^{49,51,52}$

Using hanging droplet setups and over the course of 5-15 days, we observed that the presence of $5^{\prime}$ DSCG causes all proteins, except trypsin, to form aggregates (Fig. S8, ESI $\dagger$ ). In parallel, we also studied the effect of using sodium chloride in place of 5 'DSCG at different concentrations. We found that sodium chloride is less capable of aggregating proteins; truncated pilin, trypsin and BSA did not form aggregates under the conditions we studied. A general feature of using $5^{\prime}$ DSCG to aggregate or precipitate proteins is that only relatively low concentrations of $5^{\prime} \mathrm{DSCG}$ are required. Particularly, various concentrations of less than $1 \mathrm{wt} \%$ of $5^{\prime}$ DSCG induced aggregation of the pilin protein (Fig. 9 and Table $\mathrm{S} 1 \dagger$ ). These pilin aggregates differ from other protein aggregates in two characteristics (Fig. S9, ESI $\dagger$ ). First, there are branches extending from the center of the aggregation; second, there is a dark circular region surrounding the aggregate. We observe the same aggregate morphology for pilin when varying concentrations of 5 'DSCG or sodium chloride were used (Fig. 9D). We believe that the dark region represents a concentrated solution of pilin protein.
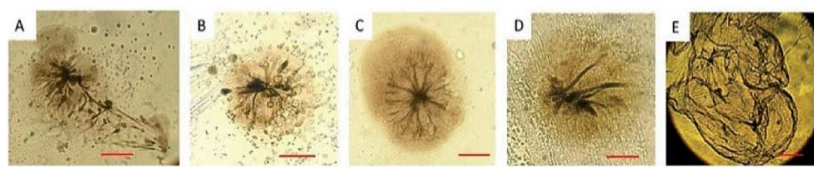

Fig. 9 Pilin aggregates induced by different precipitants in hanging droplets. The droplets $(5 \mu \mathrm{L})$ contained (A) $0.15 \mathrm{wt} \% 5^{\prime} \mathrm{DSCG}$ and $50 \mathrm{mg}$ $\mathrm{mL}^{-1}$ pilin, (B) $0.375 \mathrm{wt} \% 5^{\prime} \mathrm{DSCG}$ and $5 \mathrm{mg} \mathrm{mL}^{-1}$ pilin, (C) $0.625 \mathrm{wt} \%$ $5^{\prime} \mathrm{DSCG}$ and $25 \mathrm{mg} \mathrm{mL}^{-1}$ pilin, (D) $0.5 \mathrm{wt} \% \mathrm{NaCl}$ and $10 \mathrm{mg} \mathrm{mL}^{-1}$ pilin, and (E) 1.5 wt $\%$ PEG 8000 and $5 \mathrm{mg} \mathrm{mL}^{-1}$ pilin. The reservoir solution contained $350 \mu \mathrm{L}$ of (A) 0.30 wt\% 5'DSCG, (B) 0.75 wt\% 5'DSCG, (C) 1.25 wt\% 5'DSCG, (D) 1 wt\% NaCl, and (E) 3 wt\% PEG8000. Hanging drops kept at ambient temperature were observed over 5-15 days. All solutions were prepared using $25 \mathrm{mM}$ Tris buffer, $\mathrm{pH}=7.5$. Scale bar $=$ $380 \mu \mathrm{m}$. 


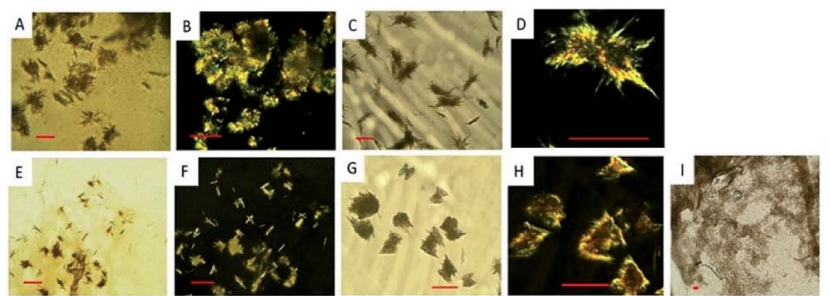

Fig. 10 Truncated pilin aggregates induced by different precipitants in hanging droplet. The droplets $(5 \mu \mathrm{L})$ contained 0.375 wt\% 5'DSCG \& $5 \mathrm{mg} \mathrm{mL}^{-1}$ truncated pilin, without polarizer (A), and under cross polars (B); $0.625 \mathrm{wt} \% 5^{\prime}$ DSCG \& $1 \mathrm{mg} \mathrm{mL}^{-1}$ truncated pilin, without polarizer (C), and under cross polars (D); $1.25 \mathrm{wt} \% 5^{\prime}$ DSCG \& $5 \mathrm{mg} \mathrm{mL}^{-1}$ truncated pilin, without polarizer (E), and under cross polars (F); $0.15 \mathrm{wt} \%$ 5'DSCG \& 0.375 wt\% $\mathrm{NaCl}$ \& $2.5 \mathrm{mg} \mathrm{mL}^{-1}$ truncated pilin without polarizer (G) and under cross polars $(\mathrm{H})$ and 25 wt\% PEG4000 \& $1 \mathrm{mg}$ $\mathrm{mL}^{-1}$ truncated pilin without polarizer (I). The reservoir solution contained $350 \mu \mathrm{L}$ of (A and B) $0.75 \mathrm{wt} \% 5^{\prime} \mathrm{DSCG}$, (C and D) $1.25 \mathrm{wt} \%$ 5'DSCG, (E and F) 2.5 wt\% 5'DSCG and (G and H) 0.3 wt\% 5'DSCG \& 0.75 wt\% $\mathrm{NaCl}$, and (I) $50 \mathrm{wt} \%$ PEG4000. Hanging drops kept at ambient temperature were observed over 5-15 days. All solutions were prepared using $25 \mathrm{mM}$ Tris buffer, $\mathrm{pH}=7.5$. Scale bar $=76 \mu \mathrm{m}$.

For the truncated pilin, we observed birefringent crystalline aggregates induced by $5^{\prime}$ DSCG (Fig. 10). Notably, the crystalline aggregates are smaller when a higher $5^{\prime}$ DSCG concentration is used as a precipitant (Fig. 10C and D vs. Fig. 10E and F). No aggregates were observed when sodium chloride was used to aggregate the truncated pilin. However, when sodium chloride was added with $5^{\prime}$ DSCG, the aggregates had smaller domains of birefringence and appeared to be more compact and polycrystalline (Fig. 10G and H). In contrast, although PEG also induced the formation of aggregates for pilin and truncated pilin, the aggregate morphology is considerably different than those induced by $5^{\prime}$ DSCG. The aggregates induced by PEG are thread-like and spread out with aqueous solution in between the threads (Fig. 9E and 10I). These results, together with those from past studies, ${ }^{\mathbf{1 0}, 11}$ suggest that $5^{\prime}$ DSCG is a potent agent for inducing protein aggregation, and when combining with other chemicals, has the potential to induce protein crystallization.

\section{Conclusions}

We have demonstrated that measuring the light scattering $\left(\mathrm{OD}_{600}\right)$ of a solution is highly effective for detecting the isodesmic assemblies of chromonic mesogens. We found that the presence of peptides can promote the formation of isodesmic assemblies at low concentrations of $5^{\prime}$ DSCG (as low as $1.5 \mathrm{wt} \%$ ). The isodesmic assembly of $5^{\prime} \mathrm{DSCG}$ in solution is corroborated by the chemical shift changes and peak broadening of proton NMR signals of $5^{\prime}$ DSCG. Water-soluble nonionic polymers, PVP, PVA and PAAm, demix with $5^{\prime}$ DSCG and promote $5^{\prime} \mathrm{DSCG}$ to form LC droplet phases but do not promote isolated isodesmic assemblies. With this general demixing observation between $5^{\prime}$ DSCG and other watersoluble molecules, we demonstrated that $5^{\prime}$ DSCG also caused the aggregation of a wide range of proteins and has the potential to be a potent protein precipitant for enabling protein crystallization.

\section{Conflicts of interest}

There are no conflicts to declare.

\section{Acknowledgements}

We thank NSF-CMMI (\#1537406) for partial funding support, Dr Makhlynets (SU) for protein expression guidance, Dr Korendovych (SU) for instrumentation, and Dr Kerwood (SU) for guidance with the use of NMR. We also thank Dr Horzempa (West Liberty University) for the sample of $P$. aeruginosa PA1244N3 (pPAC46).

\section{Notes and references}

1 J. Lydon, Liq. Cryst., 2011, 38, 1663-1681.

2 S. Zhou, A. Sokolov, O. D. Lavrentovich and I. S. Aranson, Proc. Natl. Acad. Sci. U. S. A., 2014, 111, 1265-1270.

3 P. C. Mushenheim, R. R. Trivedi, H. H. Tuson, D. B. Weibel and N. L. Abbott, Soft Matter, 2014, 10, 88-95.

4 P. C. Mushenheim, R. R. Trivedi, D. B. Weibel and N. L. Abbott, Biophys. J., 2014, 107, 255-265.

5 M. M. Genkin, A. Sokolov, O. D. Lavrentovich and I. S. Aranson, Phys. Rev. X, 2017, 7, 011029.

6 A. Sokolov, S. Zhou, O. D. Lavrentovich and I. S. Aranson, Phys. Rev. E: Stat., Nonlinear, Soft Matter Phys., 2015, 91, 013009.

7 R. R. Trivedi, R. Maeda, N. L. Abbott, S. E. Spagnolie and D. B. Weibel, Soft Matter, 2015, 11, 8404-8408.

8 C. Peng and O. D. Lavrentovich, Soft Matter, 2015, 11, 72577263.

9 S.-W. Tam-Chang and L. Huang, Chem. Commun., 2008, 1957-1967.

10 Y.-Y. Luk, C.-H. Jang, L.-L. Cheng, B. A. Israel and N. L. Abbott, Chem. Mater., 2005, 17, 4774-4782.

11 K. A. Simon, G. S. Shetye, U. Englich, L. Wu and Y.-Y. Luk, Langmuir, 2011, 27, 10901-10906.

12 P. J. Collings, A. J. Dickinson and E. C. Smith, Liq. Cryst., 2010, 37, 701-710.

13 P. J. Collings, J. N. Goldstein, E. J. Hamilton, B. R. Mercado, K. J. Nieser and M. H. Regan, Liq. Cryst. Rev., 2015, 3, 1-27.

14 P. K. Maiti, Y. Lansac, M. A. Glaser and N. A. Clark, Liq. Cryst., 2002, 29, 619-626.

15 K. A. Simon, P. Sejwal, E. R. Falcone, E. A. Burton, S. Yang, D. Prashar, D. Bandyopadhyay, S. K. Narasimhan, N. Varghese, N. S. Gobalasingham, J. B. Reese and Y.-Y. Luk, J. Phys. Chem. B, 2010, 114, 10357-10367.

16 J. S. G. Cox, G. D. Woodard and W. C. McCrone, J. Pharm. Sci., 1971, 60, 1458-1465.

17 K. A. Simon, P. Sejwal, R. B. Gerecht and Y.-Y. Luk, Langmuir, 2007, 23, 1453-1458.

18 L. Wu, J. Lal, K. A. Simon, E. A. Burton and Y.-Y. Luk, J. Am. Chem. Soc., 2009, 131, 7430-7443.

19 T. Ostapenko, Y. A. Nastishin, P. J. Collings, S. N. Sprunt, O. D. Lavrentovich and J. T. Gleeson, Soft Matter, 2013, 9, 9487-9498. 
20 L. Tortora, H.-S. Park, S.-W. Kang, V. Savaryn, S.-H. Hong, K. Kaznatcheev, D. Finotello, S. Sprunt, S. Kumar and O. D. Lavrentovich, Soft Matter, 2010, 6, 4157-4167.

21 S. Zhou, K. Neupane, Y. A. Nastishin, A. R. Baldwin, S. V. Shiyanovskii, O. D. Lavrentovich and S. Sprunt, Soft Matter, 2014, 10, 6571-6581.

22 G. R. Van Hecke, K. K. Karukstis and S. Rayermann, Phys. Chem. Chem. Phys., 2015, 17, 1047-1052.

23 A. F. Kostko, B. H. Cipriano, O. A. Pinchuk, L. Ziserman, M. A. Anisimov, D. Danino and S. R. Raghavan, J. Phys. Chem. B, 2005, 109, 19126-19133.

24 Y. A. Nastishin, H. Liu, S. V. Shiyanovskii, O. D. Lavrentovich, A. F. Kostko and M. A. Anisimov, Phys. Rev. E, 2004, 70, 151706.

25 V. R. Horowitz, L. A. Janowitz, A. L. Modic, P. A. Heiney and P. J. Collings, Phys. Rev. E: Stat., Nonlinear, Soft Matter Phys., 2005, 72, 041710.

26 M. M. J. M. Smulders, M. M. L. M. Nieuwenhuizen, d. T. F. A. T. Greef, v. d. P. P. Schoot, A. A. Schenning and E. W. B. Meijer, Chem.-Eur. J., 2010, 16, 362-367.

27 J. Henderson, J. Chem. Phys., 2000, 113, 5965-5970.

28 P. Castric, Microbiology, 1995, 141, 1247-1254.

29 J. Horzempa, T. K. Held, A. S. Cross, D. Furst, M. Qutyan, A. N. Neely and P. Castric, Clin. Vaccine Immunol., 2008, 15, 590-597.

30 F. Berride, E. Troche-Pesqueira, G. Feio, E. J. Cabrita, T. Sierra, A. Navarro-Vazquez and M. M. Cid, Soft Matter, 2017, 13, 6810-6815.

31 A. R. Ruiz-Fernandez, J. J. Lopez-Cascales, J. J. Giner-Casares, R. Araya-Maturana, F. G. Diaz-Banos and B. E. Weiss-Lopez, RSC Adv., 2016, 6, 85411-85419.

32 T. Shirai, M. Shuai, K. Nakamura, A. Yamaguchi, Y. Naka, T. Sasaki, N. A. Clark and K. V. Le, Soft Matter, 2018, 14, 1511-1516.

33 X. Ding, T. C. Stringfellow and J. R. Robinson, J. Pharm. Sci., 2004, 93, 1351-1358.

34 J. Jancarik and S.-H. Kim, J. Appl. Crystallogr., 1991, 24, 409411.

35 Y. Liu, X.-F. Zhang, C.-Y. Zhang, Y.-Z. Guo, S.-X. Xie, R.-B. Zhou, Q.-D. Cheng, E.-K. Yan, Y.-L. Liu, X.-L. Lu,
Q.-Q. Lu, H.-M. Lu, Y.-J. Ye and D.-C. Yin, CrystEngComm, 2015, 17, 5488-5495.

36 A. McPherson and B. Cudney, Acta Crystallogr., Sect. F: Struct. Biol. Commun., 2014, 70, 1445-1467.

37 J. L. Parker and S. Newstead, Protein Sci., 2012, 21, 13581365.

38 B. Cudney, S. Patel, K. Weisgraber and Y. Newhouse, Acta Crystallogr., Sect. D: Biol. Crystallogr., 1994, 50, 414-4123.

39 S. Patel, B. Cudney and A. McPherson, Biochem. Biophys. Res. Commun., 1995, 207, 819-828.

40 A. McPherson Jr, J. Biol. Chem., 1976, 251, 6300-6303.

41 K. C. Ingham, in Methods in Enzymology, ed. M. P. Deutscher, Academic Press, 1990, vol. 182, pp. 301-306.

42 X. Z. Yang, C. Y. Zhang, Q. J. Wang, Y. Z. Guo, C. Dong, E. K. Yan, W. J. Liu, X. W. Zheng and D. C. Yin, Cryst. Growth Des., 2017, 17, 6189-6200.

43 L. L. Burrows, Annu. Rev. Microbiol., 2012, 66, 493-520.

44 C. L. Giltner, Y. Nguyen and L. L. Burrows, Microbiol. Mol. Biol. Rev., 2012, 76, 740-772.

45 H. P. Hahn, Gene, 1997, 192, 99-108.

46 L. Craig and J. Li, Curr. Opin. Struct. Biol., 2008, 18, 267-277.

47 P. J. Cachia, L. M. G. Glasier, R. R. W. Hodgins, W. Y. Wong,

R. T. Irvin and R. S. Hodges, J. Pept. Res., 1998, 52, 289-299.

48 A. P. Campbell, W. Y. Wong, M. Houston, F. Schweizer, P. J. Cachia, R. T. Irvin, O. Hindsgaul, R. S. Hodges and B. D. Sykes, J. Mol. Biol., 1997, 267, 382-402.

49 B. Hazes, P. A. Sastry, K. Hayakawa, R. J. Read and R. T. Irvin, J. Mol. Biol., 2000, 299, 1005-1017.

50 L. Craig, R. K. Taylor, M. E. Pique, B. D. Adair, A. S. Arvai, M. Singh, S. J. Lloyd, D. S. Shin, E. D. Getzoff, M. Yeager, K. T. Forest and J. A. Tainer, Mol. Cell, 2003, 11, 1139-1150.

51 G. F. Audette, R. T. Irvin and B. Hazes, Biochemistry, 2004, 43, 11427-11435.

52 Y. Nguyen, S. G. Jackson, F. Aidoo, M. Junop and L. L. Burrows, J. Mol. Biol., 2010, 395, 491-503.

53 W. Paranchych, P. A. Sastry, L. S. Frost, M. Carpenter, G. D. Armstrong and T. H. Watts, Can. J. Microbiol., 1979, 25, 1175-1181. 